Lim et al.

\title{
The role of key workers in improving physical health in first episode psychosis: a scoping review
}

Jayleigh Lim ${ }^{1}$, Geoff McCombe ${ }^{1}$, Aine Harrold ${ }^{1}$, Katherine Brown ${ }^{2}$, Mary Clarke ${ }^{2}$ David Hanlon $^{2}$, Liam Hennessy ${ }^{2}$, Sinead O’Brien², John Lyne ${ }^{3,4}$, Ciaran Corcoran ${ }^{2}$, Patrick McGorry $^{3}$, Walter Cullen ${ }^{1}$

${ }^{1}$ University College Dublin, Ireland

${ }^{2}$ Health Service Executive, Ireland

${ }^{3}$ Royal College of Surgeons in Ireland

${ }^{4}$ North Dublin Mental Health Services, Ireland

${ }^{5}$ University of Melbourne, Australia

\section{Correspondence:}

Name: Aine Harrold

Address: UCD School of Medicine, Catherine McAuley Education \& Research Centre, Nelson Street, Dublin 7, Ireland

Email: aine.harrold@ucd.ie

This is the author manuscript accepted for publication and has undergone full peer review but has not been through the copyediting, typesetting, pagination and proofreading process, which may lead to differences between this version and the Version of Record. Please cite this article as doi: $10.1111 /$ eip.12937

This article is protected by copyright. All rights reserved. 


\begin{abstract}
Aim: Studies have demonstrated that a majority of the decline in health status and functioning emerges during the first few years following the onset of psychosis. This knowledge led to the development of specialized early intervention services (EIS) targeting patients experiencing their first episode of psychosis (FEP). The central component of EIS is often assertive case management delivered by a multidisciplinary team, where an appointed key worker is responsible for coordinating treatment and delivering various psychosocial interventions to service users. The aim of this scoping review was to examine how key workers can enhance the physical health outcomes in people with FEP by addressing the factors associated with increased mortality in this population.
\end{abstract}

Methods: The scoping review framework comprised a five-stage process developed by Arksey and O’Malley. The search process was guided by the Preferred Reporting Items for Systematic Reviews and Meta-Analyses (PRISMA).

Results: A total of 27 studies conducted across 10 countries were analysed. These studies discussed the various ways in which key workers can mediate enhancements in the various factors contributing to the increased mortality rates in FEP patients.

Conclusions: A broad range of key worker mediated outcomes were identified, which were broadly classified into three themes: influences on lifestyle, influences on effects of psychosis, and influences on organizational barriers. Our findings suggest that key workers primarily mediated the amelioration of psychosis-induced effects and the reduction of organizational barriers. Further trials of key worker interventions to enhance physical health outcomes in this cohort are warranted.

\title{
Keywords
}

psychosis, physical health, key worker, intervention, scoping review 


\section{1 | INTRODUCTION}

Psychosis is a clinical syndrome that affects several domains, including affective, cognitive, motivational, sensory, and social functioning. Psychosis often manifests as a symptom of psychotic-spectrum disorders, which include schizophrenia-spectrum disorders (e.g. schizophrenia and schizoaffective disorder) and affective disorders with psychotic features (e.g. bipolar disorder with psychotic features) (Breitborde \& Moe, 2016). The profound psychiatric, physical, and functional concerns associated with psychotic-spectrum disorders, has led to these illnesses being recognized as some of the most harmful illnesses affecting humanity (Breitborde \& Moe, 2016).

Poor mortality rates in adults living with psychotic-spectrum disorders are widely documented (Hayes, Marston, Walters, King, \& Osborn, 2017; Hjorthoj, Sturup, McGrath, \& Nordentoft, 2017), with current evidence suggesting a 10-25 year reduced life expectancy in patients with severe mental health disorders such as psychosis, compared with their agematched peers in the general population (De Hert et al., 2011; Dutta, Murray, Allardyce, Jones, \& Boydell, 2011; Hayes et al., 2017; Laursen, Munk-Olsen, \& Vestergaard, 2012; Laursen, Nordentoft, \& Mortensen, 2014; Nielsen, Uggerby, Jensen, \& McGrath, 2013; Saha, Chant, \& McGrath, 2007; Wahlbeck, Westman, Nordentoft, Gissler, \& Laursen, 2011). This is primarily a result of the higher rates of cardiovascular, infectious, and pulmonary diseases in this population (Dutta, Murray, Allardyce, Jones, \& Boydell, 2012; Shiers, Jones, \& Field, 2009). Additionally, poor cardiovascular health in people with schizophrenia is partly associated with unhealthy lifestyle habits. This includes high rates of alcohol, drug and tobacco use, poor levels of nutrition, and sedentariness (Aubin, Rollema, Svensson, \& Winterer, 2012; Auther et al., 2012; Cook et al., 2014; Correll et al., 2014; Gurillo, Jauhar, Murray, \& MacCabe, 2015; Krishnadas, Jauhar, Telfer, Shivashankar, \& McCreadie, 2012; McCreadie, 2003; Stubbs et al., 2018) (Fernandez-Egea et al., 2009; Spelman, Walsh, Sharifi, Collins, \& Thakore, 2007). These factors, coupled with reduced access to services, optimal treatments and timely interventions, collectively result in poorer health outcomes and 
mortality in people with psychosis (Moore, Shiers, Daly, Mitchell, \& Gaughran, 2015; Newcomer \& Hennekens, 2007).

Prospective studies of the course of these disorders have demonstrated that a majority of the decline in health status and functioning emerges during the first few years following the onset of psychosis (Lieberman et al., 2001). In addition, individuals earlier in the course of a psychotic disorder may be more responsive to both pharmacological and psychosocial treatments, as compared with individuals with more long-standing illnesses (Goldstein, 1996; Robinson et al., 1999). Drawing on these two lines of research, the first few years of psychotic-spectrum disorders are likely to be a "critical period" in which the provision of targeted, phase-specific intervention could dramatically improve the usual course of psychotic-spectrum disorders (Birchwood, Todd, \& Jackson, 1998). Hence, early detection and optimal early treatment in people experiencing their first episode of psychosis (FEP), defined as one week or more of sustained positive symptoms above the psychosis threshold for delusions and hallucinations in particular (Galletly et al., 2016), have been emphasized as best practice in FEP literature over the last decade (P. McGorry \& Edwards, 1998). This knowledge has led to the development of specialized early intervention services (EIS) in many parts of the world (Malla, Norman, McLean, Scholten, \& Townsend, 2003; P. D. McGorry, Edwards, Mihalopoulos, Harrigan, \& Jackson, 1996).

A prominent feature of many EIS is the presence of a primary point of contact between service users and mental health services, often referred to as a key worker or case manager. A key worker can be any member of the multidisciplinary EIS team and can take on a diverse range of responsibilities. Key workers can serve as the consistent point of contact between the service user (and family/carers), the EIS, and other agencies involved; provide basic psychosocial interventions, and ensure the organisation of individual care plans and service transfers for their patients. As such, there is increasing consensus that EIP key workers for those suffering from psychosis are seen as important healthcare 'resources'(Commission, 2012).A recently published Lancet Psychiatry Commission has emphasised the importance of increasing the sense of 'physical health culture' in mental health services and mental health 
staff, along with the importance of finding new ways for physical health promotion to commence from the beginning of treatment (i.e. the first-episode period) (Firth et al., 2019) The aim of this scoping review was to examine how key workers can enhance the physical health of people with FEP by mediating enhancements in various factors contributing to the increased mortality rates in this population. A scoping review methodology was selected to explore this topic, as opposed to a systematic review, in order to give a clear indication of the volume of literature and to include studies where many different study designs were used. Employing the Arksey and O’Malley framework allowed for a rigorous and transparent methodological approach to identify and map the available evidence in this relatively new topic area (Arksey \& O'Malley, 2005).

\section{2 | METHODS}

For the purposes of this study, the definition of a scoping review as a type of research synthesis that aims to 'map the literature on a particular topic or research area and provide an opportunity to identify key concepts; gaps in the research; and types and sources of evidence to inform practice, policymaking, and research'(Daudt, van Mossel, \& Scott, 2013) was employed.

The methodologically rigorous scoping review framework comprising of an iterative fivestage process, as developed by Arksey and O’Malley(Arksey \& O'Malley, 2005) with later recommendations by Levac et al.(Levac, Colquhoun, \& O'Brien, 2010), was adopted in this review to undertake a comprehensive and systematic search of the current literature examining the role of a key worker in enhancing the physical health outcomes in individuals with FEP. The five stages of the scoping review process were:

\subsection{Stage 1: Identifying the research question}

The objectives of this review were focused on extant knowledge and gaps around the content, evaluation, and effectiveness of key workers in enhancing the physical health outcomes in 
individuals who have experienced their first psychotic episode. Three research questions were developed to guide the review:

- What is the extent and nature of research regarding the role of key workers in the context of patients with FEP?

- What key worker roles have been identified?

- What are other potential roles that key workers can play to enhance physical health outcomes in FEP?

\section{2 | Stage 2: Identifying relevant studies}

The comprehensive three-step search strategy recommended in standard Joanna Briggs Institute (JBI) systematic reviews(Aromataris \& Riitano, 2014) was utilized in this review in order to identify both published and unpublished (grey literature) evidence. The first step was an initial limited search of relevant databases such as PubMed, followed by an analysis of the text words contained in the title and abstract, and of the index terms used to describe the article. A second search using all identified keywords and index terms was then undertaken across all included databases. Thirdly, the reference list of all identified reports and articles were manually searched for additional relevant studies. Only studies published in English were considered for inclusion in this review. No date limitation was imposed upon the search strategies.

Electronic databases searched included: PubMed, PsycINFO, Embase, CINAHL, and the Cochrane library. In addition, electronically available peer-reviewed journals were handsearched. Search terms agreed upon, and the general search strategy is illustrated in Fig. 1. Citations were managed using the bibliographic software manager EndNote.

\subsection{Stage 3: Study selection}


The selection process consisted of two levels of screening: (1) a title and abstract review and (2) a full-text review. The PRISMA flow diagram as illustrated in Fig. 2 outlines the results of the literature search.

Consistent with the scoping review methodology, this study was broad in its inclusion of different types of literature(Arksey \& O'Malley, 2005; Levac et al., 2010; Pham et al., 2014), and an assessment of methodological quality was not performed.. Both peer-reviewed and grey literature were searched, with no methodological requirement for study inclusion. This facilitated the inclusion of an array of literature, which included quantitative, qualitative and mixed-method studies, as well as systematic reviews and meta-analyses. Protocols were excluded. The eligibility criteria for content were developed according to the JBI reviewer's manual (2015)(Peters et al., 2015), which suggest the use of the mnemonic PCC (population, concept, and context) to target the desired focus and scope for the review:

- Population: The article had to focus on individuals with FEP. Articles presenting research on participants of any age, sex and diagnosis were included, so long as they met the criteria of having experienced a FEP.

- Concept: The article had to explain, evaluate, describe, or propose the role of a key worker in influencing the physical health outcomes of patients with FEP.

- Context: The article had to focus on the care administered by a key worker in the context of early intervention services for FEP patients. Articles presenting research from any country, and on both in-patient and out-patient care were included.

\subsection{Stage 4: Charting the data}

Data from included articles were organized into a table to facilitate comparison and thematic analysis (Table 1). The following data were extracted from the articles:

- Author(s), year of publication, study location

- Study populations (carer group; care recipient group) 
- Intervention type or Study design

- Comparator (if any)

- Outcome measures

\section{5 | Stage 5: Collating, summarizing and reporting the results}

A subsequent table was developed to summarize the identified key worker mediated outcomes (Table 2) in the context of the various contributors to the poor physical health in FEP patients.

\section{3 | RESULTS}

\subsection{Search Results}

The initial search identified 999 records, of which 15 were identified to be relevant to the roles of key workers in enhancing physical health outcomes in FEP patients. A further 12 records were identified through the review process, including relevant published studies of study protocols that came up in the search, as well as relevant studies identified from screening the reference lists of included records. The search process is summarised in Figure 2 as guided by the Preferred Reporting Items for Systematic Reviews and Meta-Analyses (PRISMA) diagram. A total of 27 records were included in the review.

\subsection{Key Worker Mediated Physical Health Outcomes}

\subsubsection{Description of Included Studies}

The 27 records included identified influences of key workers on various factors contributing to the poorer physical health outcomes observed in the FEP cohort. These factors include poor lifestyle choices, effects of psychosis, and organizational barriers, as summarized in Figure 3. Both quantitative and qualitative studies were included, with no restriction on study design. Papers included were published between 2004 and 2018. Study locations included a range of countries.

This article is protected by copyright. All rights reserved. 
A total of 20 quantitative and seven qualitative studies were included in the review. Early intervention programs represented in the studies include: the OPUS and OPUS-II trials in Denmark, the ETHOS and LEO programmes in England, the TIPP-Lausanne programme in Switzerland, the EPIP in Singapore, the GET UP PIANO trial in Italy, the J-CAP trial in Japan, the EASY and JCEP programmes in Hong Kong, the Parachute project in Sweden, the EPPIC and EPP programmes in Australia, and the PEPP programme in Canada. General characteristics of studies under this theme are as summarized in Table 1.

\subsubsection{Integrated findings}

Studies included identified various key worker mediated influences on physical health outcomes, which can be broadly classified into three themes: (1) Influences on Lifestyle, (2) Influences on Effects of Psychosis, and (3) Influences on Organizational Barriers. The themes and outcomes explored by the included records are summarized in Table 2 .

\subsection{Influences on Lifestyle.}

The unhealthy lifestyle of FEP patients, which include greater sedentariness, poor diet, tobacco smoking, alcohol misuse and substance abuse contribute to the higher risk of both natural and unnatural causes of death in this group. Two key worker mediated outcomes were identified under this theme: a reduction in comorbid substance misuse, and enhanced engagement in discussions on physical health.

\subsubsection{Comorbid substance misuse.}

Of the 27 studies, five quantitative studies(Albert et al., 2017; Bertelsen et al., 2008; L. Petersen, P. Jeppesen, et al., 2005; L. Petersen, M. Nordentoft, et al., 2005; Singh et al., 2007) discussed the effect of ACM on co-morbid substance misuse in FEP patients. Only two studies reported a significant effect on this measure favouring the experimental intervention. Of the three studies that reported an absence of significant effect of the intervention on this measure(Albert et al., 2017; Bertelsen et al., 2008; Singh et al., 2007), one reported outcomes of the OPUS trial at five-year follow-up(Bertelsen et al., 2008), suggesting the unsustainability of the positive effects achieved in the earlier follow-up points. 


\subsection{2. | Discussions on physical health}

Two qualitative studies(Lester et al., 2012; Wong et al., 2017) discussed the role of key workers in facilitating discussions on physical health issues. Of these, one study identified enhanced engagement in such discussions that was facilitated by a key worker(Wong et al., 2017). The study found that key workers engaged FEP patients on various topics, including diet and exercise to manage weight gain from psychotropic medications. One study highlighted the absence of such discussions(Lester et al., 2012).

\subsection{Influences on effects of psychosis}

Various psychosis-induced risk factors such as the side effects of antipsychotic medications, reduced motivation and capacity to seek help, psychotic symptoms, social isolation and unemployment contribute to the increased risk of natural and unnatural deaths in FEP patients. Three key worker mediated outcomes were identified under this theme: enhanced symptomatic recovery, enhanced social outcomes, and enhanced illness management.

\subsubsection{Symptomatic recovery}

Of the 27 studies, 13 quantitative studies discussed the effect of ACM on symptomatic recovery, and two qualitative studies discussed in detail the effects key workers had on this outcome. Indicators for this outcome include a reduction in severity of psychotic and negative symptoms, an enhanced rate/length of symptom remission, a reduction in rates of relapse, a reduction in depressive symptoms, a reduction in suicidal behaviour/ideation, and enhanced global functioning.

Severity of psychotic and negative symptoms.

11 quantitative studies identified the severity of psychotic and negative symptoms as an outcome measure, of which seven demonstrated reduced severity in these symptoms following the experimental intervention(Chen et al., 2011; L. Petersen, P. Jeppesen, et al., 2005; L. Petersen, M. Nordentoft, et al., 2005; Ruggeri et al., 2015; Singh et al., 2007; Thorup et al., 2005; Verma, Poon, Lee, Rao, \& Chong, 2012), one demonstrated a reduced 
severity in negative symptoms but not psychotic symptoms(Chang et al., 2015), while three demonstrated no such improvement(Albert et al., 2017; Bertelsen et al., 2008; Secher et al., 2015). Generally, the quantitative studies revealed that the case management approach adopted by various EIS effected greater improvements in symptom severity, as compared to either other FEP patients who received standard care, or to their baseline symptoms.

\section{Symptom remission and rate of relapse.}

Six quantitative studies identified symptom remission as an outcome measure, of which three demonstrated enhanced remission following the experimental intervention(Chen et al., 2011; Malla et al., 2017; Nishida et al., 2018), while three did not(Albert et al., 2017; Bertelsen et al., 2008; Chang et al., 2015). Two of the six studies also identified rate of relapse as an outcome measure, but both failed to demonstrate improvements in the intervention group(Chang et al., 2015; Chen et al., 2011).

One qualitative study identified the role of a key worker in reducing the rate of relapse(R. Tindall, Francey, \& Hamilton, 2015). The study found the fear of relapse and of being readmitted to be essential factors promoting engagement of participants with their key workers. In addition, participants viewed talking with their key workers about how they felt and what they were going through to be helpful in maintaining recovery and essential in preventing relapses of psychosis.

\subsubsection{Social outcomes}

Of the 27 studies, 11 quantitative studies discussed the effect of ACM on social outcomes, and five qualitative studies discussed in detail the effects key workers had on this outcome. Indicators for this outcome include: enhanced practical and/or emotional support, enhanced social participation, improvements in social and vocational functioning and/or employment status, enhanced independence, and reduced relatives’ burden of illness.

Practical and/or emotional support. 
Five qualitative studies identified the role key workers played in providing practical and/or emotional support to FEP patients. All studies collected data through semi-structured interviews, apart from one which conducted focus group discussions. Most studies emphasized the value of key workers in helping to meet the identified needs of FEP patients, both practically and emotionally

\section{Social participation.}

Two qualitative studies identified the role key workers played in enhancing the social participation of FEP patients. In both studies, key workers were found to play an essential role in encouraging the participation of FEP patients in various activities, which aided them in overcoming the lack of motivation stemming from their illness(Lester et al., 2012; Windell \& Norman, 2012), and presented opportunities for normative social inclusion(Windell \& Norman, 2012).

\subsubsection{Illness management}

Of the 27 studies, 14 quantitative studies discussed the effect of ACM on illness management, and five qualitative studies discussed in detail the effects key workers had on this outcome. Indicators for this outcome include: reduced risk/number/length of hospital admissions, reduced emergency department visits, enhanced education on illness and management strategies, enhanced adherence to medication, and enhanced crisis management.

\section{Risk/Number/Length of Hospital Admissions and Emergency Department Visits.}

Thirteen quantitative studies identified risk/number/length of hospital admissions as an outcome measure, of which six demonstrated significant effects favouring the experimental intervention, while seven did not. Of the six studies that favoured the intervention in this measure(Baumann et al., 2013; Bertelsen et al., 2008; Chen et al., 2011; L. Petersen, P. Jeppesen, et al., 2005; Randall et al., 2015; Singh \& Fisher, 2004), one reported outcomes of a meta-analysis of the effect of EIS care on the usage of inpatient services(Randall et al., 2015). The study found that FEP patients who received EIS care had a significantly reduced 
risk of being hospitalized at least once during the follow-up period, and also had significantly reduced inpatient bed-day usage.

\section{Education on Illness and Management Strategies.}

One quantitative study identified enhancement in education on illness and management strategies brought about by the intervention. The study found that patients who received care under the EPIP were more likely to have received education about their prescribed medications and side effects, as compared to the control group.

Five qualitative studies identified key workers to be essential in mediating an improvement in this outcome. Key workers were found to be of great importance in helping FEP patients come to terms with and make sense of their experience of psychosis by explaining how it came about(Lai, Chang, Tam, Hui, \& Chen, 2013; Lester et al., 2012; R. Tindall et al., 2015; Windell \& Norman, 2012), and its relationship to past experiences and emotions(Lai et al., 2013). This was thought to have given them a greater sense of control over the illness

\subsection{Influences on Organizational Barriers}

Various organizational barriers such as reduced access to healthcare, lack of physical health monitoring and inadequate care provision have been identified as factors contributing to the increased risk of natural deaths in FEP patients. Three key worker mediated outcomes were identified under this theme: enhanced continuity of care, enhanced quality of care, and enhanced access to care.

\subsubsection{Continuity of care}

Of the 27 studies, 13 quantitative studies discussed the effect of ACM on continuity of care, and two qualitative studies discussed in detail the effects key workers had on this outcome. Indicators for this outcome include: enhanced engagement with services and increased outpatient service use.

Engagement with services. 
Ten quantitative studies identified engagement with services as an outcome measure, of which all but one demonstrated significant effects of the experimental intervention on this outcome. FEP patients who received the intervention were found to be less likely to discontinue or drop out of treatment(Albert et al., 2017; Ando, Nishida, \& Koike, 2013; Baumann et al., 2013; Chen et al., 2011; Chong et al., 2006; Malla et al., 2017; Nishida et al., 2018; Lone Petersen et al., 2005), and to have greater frequency of contact with their key workers(Singh \& Fisher, 2004) as compared to patients who did not.

Two qualitative studies identified the crucial role of key workers in enhancing engagement of FEP patients with the EIS and their key workers. Various factors were found to promote engagement in this cohort, of which the therapeutic relationship between the key worker and client was described as a key facilitator of engagement(R. Tindall et al., 2015; R. M. Tindall, Simmons, Allott, \& Hamilton, 2018).

\section{Outpatient service use.}

Seven quantitative studies identified outpatient service use as an outcome measure, of which five found the experimental intervention to be superior in enhancing outpatient attendances, as measured by number of contacts per year or number of defaulted appointments(Albert et al., 2017; Chang et al., 2015; Chen et al., 2011; Chong et al., 2006; Lone Petersen et al., 2005).

\subsubsection{Quality of care.}

Of the 27 studies, nine studies discussed the effect of ACM on quality of care. Indicators for this outcome include: enhanced health assessment/monitoring, enhanced collaboration with other care providers, enhanced treatment satisfaction of clients, enhanced treatment satisfaction of caregivers, and a greater number of interventions received.

Health assessment/monitoring. 
One quantitative study found that the intervention led to enhancements to health assessment/monitoring.

One qualitative study identified the role key workers played in enhancing monitoring of FEP patients(Wong et al., 2017). . Key workers were found to provide comprehensive monitoring of patients in the biological, psychological, social and spiritual domains of their health, which was deemed important given the multiple factors that could contribute to FEP patients' risk of relapse.

Collaboration with other care providers.

Two qualitative studies identified enhanced collaboration with other care providers that was mediated by key workers. In one study, the partnership between key workers and other professionals within the multidisciplinary team, as well as non-professional carers was found to be essential in enhancing the management of FEP patients' illness and optimizing their psychosocial functioning(Wong et al., 2017).

\subsubsection{Access to care}

Of the 27 studies, two quantitative discussed the effect of ACM on access to care. The indicator identified for this outcome was an enhanced access to psychiatric services.

Access to psychiatric services.

Two quantitative studies identified significant effects in favour of the intervention with regards to the access of FEP patients to psychiatric services. 


\section{4 | DISCUSSION}

\subsection{Summary of key findings}

This review highlights the essential role that key workers play in mediating enhancements in the physical health outcomes in patients with FEP by targeting the factors contributing to the high mortality rates in this cohort. This is largely a result of the diverse responsibilities that key workers take on, which include but is not limited to the coordination of services, provision of psycho-education, and assisting FEP patients with meeting their various practical and emotional needs. Overall, our findings suggest that key workers are capable of enhancing the physical health outcomes of FEP patients through their influence on various factors contributing to the greater mortality rates in this cohort.

\subsubsection{Key worker roles in FEP}

It is important to acknowledge that achieving the identified positive outcomes is largely contingent on various factors. One such factor is the quality of the therapeutic relationship between key workers and their clients. The critical importance of service-provider relationships in promoting recovery has been highlighted in individuals with more longstanding mental illness(Mancini, 2007), and has been suggested to be especially important in the initial phase of the illness(Bradshaw, Armour, \& Roseborough, 2007; McCann \& Clark, 2004), and in EIS in particular(Larsen, 2007; O'Toole et al., 2004). Other factors are the workload of key workers, and the amount of training they have received. While the general roles and responsibilities of key workers in various countries are similar, their workload and training received often differ depending on the resources of the EIS. This would in turn translate to the different quality of care provided and standard of psychosocial interventions delivered(Juliana, Sarah, \& Elizabeth, 2016)

\subsubsection{Potential extensions of key worker roles}

The review failed to identify significant key worker mediated outcomes with regards to influencing changes in the poor lifestyle habits often present in this cohort. Few studies 
touched on comorbid substance misuse in FEP patients, of which only the OPUS trial managed to achieve significant outcomes. Discussions regarding physical health were also sparsely mentioned in the records included. In addition, none of the studies included physical health monitoring, or physical health parameters as part of their outcome measures. Given the excess of physical health conditions observed in FEP patients, there is an urgent need for more efforts to be invested in improving not just the mental health outcomes of FEP patients, but also their physical health.

Another potential role of a key worker in improving physical health outcomes in patients with FEP, is as a 'referrer' to other relevant health professionals. Using key workers to link patients to allied health professionals such as dieticians and exercise physiologists, who are perhaps better skilled and resourced to deliver the level of physical health intervention required by people with FEP, may be a useful way of utilising key workers to improve the physical health outcomes of patients.

\subsection{Future research}

When considering the physical health of people with FEP, it is important to consider them holistically by taking into account factors contributing to their biological, psychological and social wellbeing. While various factors were considered in this review, further investigations to establish stronger links between the role of key workers and the enhancements in outcomes identified would be of great value. Studies involving multiple phases that include both qualitative and qualitative aspects, for instance a randomized controlled trial to evaluate an intervention followed by a cross-sectional study to elicit the specific component of the intervention that contributed to the outcomes identified, would be especially desirable for the identification of key worker mediated influences on outcomes. In addition, further investigations of how the strengths and unique position of key workers can be leveraged to enhance physical health screening and implement lifestyle interventions in this cohort is warranted.

\subsection{Limitations}


There were some limitations to our review, which should be considered when interpreting the findings. Firstly, it should be acknowledged that the scoping review methodology itself gives rise to some limitations. While we aimed to be comprehensive in our approach, there is a possibility that not all publications relevant to the inclusion criteria were identified by the searches or databases used. In addition, scoping reviews do not include an assessment of study quality as the focus is on covering the range of work that informs the topic rather than limiting the work to studies that meet particular standards of scientific rigour. Secondly, only articles published in English were considered for inclusion in our review, which could have resulted in the exclusion of equally relevant literature published in other languages.

\subsection{Conclusion}

This review sought to scope extant research literature to identify key worker mediated enhancement of physical health outcomes in people experiencing their first episode of psychosis. A broad array of outcomes was identified across the 27 reviewed articles, which were categorized under three main themes: influences on lifestyle, influences on effects of psychosis, and influences on organizational barriers. While significant key worker mediated enhancements were identified, there was an evident paucity of studies identifying physical health monitoring or physical health parameters as outcome measures. Suggestions were made as to how key workers can enhance cardio-metabolic screening and contribute to the integration of lifestyle interventions into existing EIS programs. Further investigations of how the strengths of key workers can be leveraged to deliver interventions to prevent the development of physical health comorbidities in this vulnerable cohort is warranted.

\section{Conflict of Interest Statement}

All authors state that they have no conflicts of interest to declare. 
Lim et al.

This article is protected by copyright. All rights reserved. 


\section{REFERENCES}

Albert, N., Melau, M., Jensen, H., Emborg, C., Jepsen, J. R., Fagerlund, B., . . Nordentoft, M. (2017). Five years of specialised early intervention versus two years of specialised early intervention followed by three years of standard treatment for patients with a first episode psychosis: randomised, superiority, parallel group trial in Denmark (OPUS II). Bmj, 356, i6681. doi:10.1136/bmj.i6681

Ando, S., Nishida, A., \& Koike, S. (2013). A team intervention for first-episode psychosis in Japan. Psychiatric Services, 64(9), 932-933. doi:http://dx.doi.org/10.1176/appi.ps.005132012

Arksey, H., \& O'Malley, L. (2005). Scoping studies: towards a methodological framework. International journal of social research methodology, 8(1), 19-32.

Aromataris, E., \& Riitano, D. (2014). Constructing a search strategy and searching for evidence. A guide to the literature search for a systematic review. Am J Nurs, 114(5), 49-56. doi:10.1097/01.NAJ.0000446779.99522.f6

Aubin, H. J., Rollema, H., Svensson, T. H., \& Winterer, G. (2012). Smoking, quitting, and psychiatric disease: a review. Neurosci Biobehav Rev, 36(1), 271-284. doi:10.1016/j.neubiorev.2011.06.007

Auther, A. M., McLaughlin, D., Carrión, R. E., Nagachandran, P., Correll, C. U., \& Cornblatt, B. A. (2012). Prospective Study of Cannabis Use in Adolescents at Clinical High-Risk for Psychosis: Impact on Conversion to Psychosis and Functional Outcome. Psychol Med, 42(12), 2485-2497. doi:10.1017/s0033291712000803

Baumann, P. S., Crespi, S., Marion-Veyron, R., Solida, A., Thonney, J., Favrod, J., . . Conus, P. (2013). Treatment and early intervention in psychosis program (TIPP-Lausanne): Implementation of an early intervention programme for psychosis in Switzerland. Early Intervention in Psychiatry, 7(3), 322-328. doi:10.1111/eip.12037

Bertelsen, M., Jeppesen, P., Petersen, L., Thorup, A., Ohlenschlaeger, J., le Quach, P., . . Nordentoft, M. (2008). Five-year follow-up of a randomized multicenter trial of intensive early intervention vs standard treatment for patients with a first episode of psychotic illness: the OPUS trial. Arch Gen Psychiatry, 65(7), 762-771. doi:10.1001/archpsyc.65.7.762

Birchwood, M., Todd, P., \& Jackson, C. (1998). Early intervention in psychosis. The critical period hypothesis. Br J Psychiatry Suppl, 172(33), 53-59.

Bradshaw, W., Armour, M. P., \& Roseborough, D. (2007). Finding a place in the world: The experience of recovery from severe mental illness. Qualitative Social Work: Research and Practice, 6(1), 27-47. doi:http://dx.doi.org/10.1177/1473325007074164

Breitborde, N. J. K., \& Moe, A. M. (2016). Early Intervention in Psychosis in the United States: From Science to Policy Reform. Policy Insights from the Behavioral and Brain Sciences, 4(1), 7987. doi:10.1177/2372732216683965

Chang, W. C., Chan, G. H., Jim, O. T., Lau, E. S., Hui, C. L., Chan, S. K., . . Chen, E. Y. (2015). Optimal duration of an early intervention programme for first-episode psychosis: randomised controlled trial. Br J Psychiatry, 206(6), 492-500. doi:10.1192/bjp.bp.114.150144

Chen, E. Y., Tang, J. Y., Hui, C. L., Chiu, C. P., Lam, M. M., Law, C. W., . . Honer, W. G. (2011). Three-year outcome of phase-specific early intervention for first-episode psychosis: a cohort study in Hong Kong. Early Interv Psychiatry, 5(4), 315-323. doi:10.1111/j.17517893.2011.00279.x 
Chong, S. A., Vaingankar, J. A., Chan, Y. H., Jauhar, N., Kwok, V., Soo, S. C., . . Verma, S. (2006). Assessing the quality of care for patients with first-episode psychosis. Singapore Med J, 47(10), 882-885.

Commission, S. (2012). The abandoned illness: a report from the Schizophrenia Commission. London: Rethink Mental Illness.

Cook, B. L., Wayne, G. F., Kafali, E. N., Liu, Z., Shu, C., \& Flores, M. (2014). Trends in smoking among adults with mental illness and association between mental health treatment and smoking cessation. Jama, 311(2), 172-182. doi:10.1001/jama.2013.284985

Correll, C. U., Robinson, D. G., Schooler, N. R., Brunette, M. F., Mueser, K. T., Rosenheck, R. A., . . . Kane, J. M. (2014). Cardiometabolic risk in patients with first-episode schizophrenia spectrum disorders: baseline results from the RAISE-ETP study. JAMA Psychiatry, 71(12), 1350-1363. doi:10.1001/jamapsychiatry.2014.1314

Daudt, H. M., van Mossel, C., \& Scott, S. J. (2013). Enhancing the scoping study methodology: a large, inter-professional team's experience with Arksey and O'Malley's framework. BMC Med Res Methodol, 13, 48. doi:10.1186/1471-2288-13-48

De Hert, M., Cohen, D., Bobes, J., Cetkovich-Bakmas, M., Leucht, S., Ndetei, D. M., . . Correll, C. U. (2011). Physical illness in patients with severe mental disorders. II. Barriers to care, monitoring and treatment guidelines, plus recommendations at the system and individual level. World Psychiatry, 10(2), 138-151.

Dutta, R., Murray, R. M., Allardyce, J., Jones, P. B., \& Boydell, J. (2011). Early risk factors for suicide in an epidemiological first episode psychosis cohort. Schizophr Res, 126(1-3), 11-19. doi:10.1016/j.schres.2010.11.021

Dutta, R., Murray, R. M., Allardyce, J., Jones, P. B., \& Boydell, J. E. (2012). Mortality in first-contact psychosis patients in the U.K.: a cohort study. Psychol Med, 42(8), 1649-1661. doi:10.1017/s0033291711002807

Fernandez-Egea, E., Bernardo, M., Donner, T., Conget, I., Parellada, E., Justicia, A., . . K Kirkpatrick, B. (2009). Metabolic profile of antipsychotic-naive individuals with non-affective psychosis. Br J Psychiatry, 194(5), 434-438. doi:10.1192/bjp.bp.108.052605

Firth, J., Siddiqi, N., Koyanagi, A., Siskind, D., Rosenbaum, S., Galletly, C., . . . Carvalho, A. F. (2019). The Lancet Psychiatry Commission: a blueprint for protecting physical health in people with mental illness. The Lancet Psychiatry, 6(8), 675-712.

Galletly, C., Castle, D., Dark, F., Humberstone, V., Jablensky, A., Killackey, E., . . Tran, N. (2016). Royal Australian and New Zealand College of Psychiatrists clinical practice guidelines for the management of schizophrenia and related disorders. Aust N Z J Psychiatry, 50(5), 410-472. doi:10.1177/0004867416641195

Goldstein, M. J. (1996). Psycho-education and family treatment related to the phase of a psychotic disorder. International Clinical Psychopharmacology, 11(Suppl 2), 77-83. doi:10.1097/00004850-199605002-00013

Gurillo, P., Jauhar, S., Murray, R. M., \& MacCabe, J. H. (2015). Does tobacco use cause psychosis? Systematic review and meta-analysis. Lancet Psychiatry, 2(8), 718-725. doi:10.1016/s22150366(15)00152-2

Hayes, J. F., Marston, L., Walters, K., King, M. B., \& Osborn, D. P. J. (2017). Mortality gap for people with bipolar disorder and schizophrenia: UK-based cohort study 2000-2014. Br J Psychiatry, 211(3), 175-181. doi:10.1192/bjp.bp.117.202606

Hjorthoj, C., Sturup, A. E., McGrath, J. J., \& Nordentoft, M. (2017). Years of potential life lost and life expectancy in schizophrenia: a systematic review and meta-analysis. Lancet Psychiatry, 4(4), 295-301. doi:10.1016/s2215-0366(17)30078-0 
Juliana, O., Sarah, G., \& Elizabeth, K. (2016). Delivering Cognitive-Behavioural Family Interventions for Schizophrenia. Australian Psychologist, 51(1), 52-61. doi:doi:10.1111/ap.12179

Krishnadas, R., Jauhar, S., Telfer, S., Shivashankar, S., \& McCreadie, R. G. (2012). Nicotine dependence and illness severity in schizophrenia. Br J Psychiatry, 201(4), 306-312. doi:10.1192/bjp.bp.111.107953

Lai, D. C., Chang, W. C., Tam, W., Hui, C., \& Chen, E. (2013). Cognitive and affective perspectives on formation and maintenance of grandiose delusions of a patient with schizophrenia. East Asian Archives of Psychiatry, 23(4), 160-163.

Larsen, J. A. (2007). Symbolic healing of early psychosis: psychoeducation and sociocultural processes of recovery. Cult Med Psychiatry, 31(3), 283-306. doi:10.1007/s11013-007-9055-1

Laursen, T. M., Munk-Olsen, T., \& Vestergaard, M. (2012). Life expectancy and cardiovascular mortality in persons with schizophrenia. Curr Opin Psychiatry, 25(2), 83-88. doi:10.1097/YCO.0b013e32835035ca

Laursen, T. M., Nordentoft, M., \& Mortensen, P. B. (2014). Excess early mortality in schizophrenia. Annu Rev Clin Psychol, 10, 425-448. doi:10.1146/annurev-clinpsy-032813-153657

Lester, H., Khan, N., Jones, P., Marshall, M., Fowler, D., Amos, T., \& Birchwood, M. (2012). Service users' views of moving on from early intervention services for psychosis: a longitudinal qualitative study in primary care. Br J Gen Pract, 62(596), e183-190. doi:10.3399/bjgp12X630070

Levac, D., Colquhoun, H., \& O'Brien, K. K. (2010). Scoping studies: advancing the methodology Implement Sci (Vol. 5, pp. 69).

Lieberman, J. A., Perkins, D., Belger, A., Chakos, M., Jarskog, F., Boteva, K., \& Gilmore, J. (2001). The early stages of schizophrenia: speculations on pathogenesis, pathophysiology, and therapeutic approaches. Biol Psychiatry, 50(11), 884-897.

Malla, A., Joober, R., Iyer, S., Norman, R., Schmitz, N., Brown, T., . . Abadi, S. (2017). Comparing three-year extension of early intervention service to regular care following two years of early intervention service in first-episode psychosis: a randomized single blind clinical trial. World Psychiatry, 16(3), 278-286. doi:10.1002/wps.20456

Malla, A., Norman, R., McLean, T., Scholten, D., \& Townsend, L. (2003). A Canadian programme for early intervention in non-affective psychotic disorders. Aust N Z J Psychiatry, 37(4), 407413. doi:10.1046/j.1440-1614.2003.01194.x

Mancini, M. A. (2007). A Qualitative Analysis of Turning Points in the Recovery Process. American Journal of Psychiatric Rehabilitation, 10(3), 223-244. doi:10.1080/15487760701508359

McCann, T. V., \& Clark, E. (2004). Advancing self-determination with young adults who have schizophrenia. J Psychiatr Ment Health Nurs, 11(1), 12-20.

McCreadie, R. G. (2003). Diet, smoking and cardiovascular risk in people with schizophrenia: descriptive study. Br J Psychiatry, 183, 534-539.

McGorry, P., \& Edwards, J. (1998). The feasibility and effectiveness of early intervention in psychotic disorders: The Australian experience (Vol. 13).

McGorry, P. D., Edwards, J., Mihalopoulos, C., Harrigan, S. M., \& Jackson, H. J. (1996). EPPIC: an evolving system of early detection and optimal management. Schizophr Bull, 22(2), 305-326.

Moore, S., Shiers, D., Daly, B., Mitchell, A. J., \& Gaughran, F. (2015). Promoting physical health for people with schizophrenia by reducing disparities in medical and dental care. Acta Psychiatr Scand, 132(2), 109-121. doi:10.1111/acps.12431

Newcomer, J. W., \& Hennekens, C. H. (2007). Severe mental illness and risk of cardiovascular disease. Jama, 298(15), 1794-1796. doi:10.1001/jama.298.15.1794 
Nielsen, R. E., Uggerby, A. S., Jensen, S. O., \& McGrath, J. J. (2013). Increasing mortality gap for patients diagnosed with schizophrenia over the last three decades--a Danish nationwide study from 1980 to 2010. Schizophr Res, 146(1-3), 22-27. doi:10.1016/j.schres.2013.02.025

Nishida, A., Ando, S., Yamasaki, S., Koike, S., Ichihashi, K., Miyakoshi, Y., . . Okazaki, Y. (2018). A randomized controlled trial of comprehensive early intervention care in patients with firstepisode psychosis in Japan: 1.5-year outcomes from the J-CAP study. J Psychiatr Res, 102, 136-141. doi:10.1016/j.jpsychires.2018.04.007

O'Toole, M. S., Ohlsen, R. I., Taylor, T. M., Purvis, R., Walters, J., \& Pilowsky, L. S. (2004). Treating first episode psychosis--the service users' perspective: a focus group evaluation. $J$ Psychiatr Ment Health Nurs, 11(3), 319-326. doi:10.1111/j.1365-2850.2004.00730.x

Peters, M. D., Godfrey, C. M., Khalil, H., McInerney, P., Parker, D., \& Soares, C. B. (2015). Guidance for conducting systematic scoping reviews. Int J Evid Based Healthc, 13(3), 141146. doi:10.1097/xeb.0000000000000050

Petersen, L., Jeppesen, P., Thorup, A., Abel, M.-B., Øhlenschlæger, J., Christensen, T. Ø., . . . Nordentoft, M. (2005). A randomised multicentre trial of integrated versus standard treatment for patients with a first episode of psychotic illness. Bmj, 331(7517), 602.

Petersen, L., Jeppesen, P., Thorup, A., Abel, M. B., Ohlenschlaeger, J., Christensen, T. O., . . . Nordentoft, M. (2005). A randomised multicentre trial of integrated versus standard treatment for patients with a first episode of psychotic illness. Bmj, 331(7517), 602. doi:10.1136/bmj.38565.415000.E01

Petersen, L., Nordentoft, M., Jeppesen, P., Ohlenschaeger, J., Thorup, A., Christensen, T. O., . . Jorgensen, P. (2005). Improving 1-year outcome in first-episode psychosis: OPUS trial. Br J Psychiatry Suppl, 48, s98-103. doi:10.1192/bjp.187.48.s98

Pham, M. T., Rajic, A., Greig, J. D., Sargeant, J. M., Papadopoulos, A., \& McEwen, S. A. (2014). A scoping review of scoping reviews: advancing the approach and enhancing the consistency. Res Synth Methods, 5(4), 371-385. doi:10.1002/jrsm.1123

Randall, J. R., Vokey, S., Loewen, H., Martens, P. J., Brownell, M., Katz, A., . . Chateau, D. (2015). A Systematic Review of the Effect of Early Interventions for Psychosis on the Usage of Inpatient Services. Schizophr Bull, 41(6), 1379-1386. doi:10.1093/schbul/sbv016

Robinson, D. G., Woerner, M. G., Alvir, J. M., Geisler, S., Koreen, A., Sheitman, B., . . Lieberman, J. A. (1999). Predictors of treatment response from a first episode of schizophrenia or schizoaffective disorder. Am J Psychiatry, 156(4), 544-549. doi:10.1176/ajp.156.4.544

Ruggeri, M., Bonetto, C., Lasalvia, A., Fioritti, A., De Girolamo, G., Santonastaso, P., . . Meneghelli, A. (2015). Feasibility and effectiveness of a multi-element psychosocial intervention for firstepisode psychosis: Results from the cluster-randomized controlled GET UP PIANO trial in a catchment area of 10 million inhabitants. Schizophrenia bulletin, 41(5), 1192-1203. doi:10.1093/schbul/sbv058

Saha, S., Chant, D., \& McGrath, J. (2007). A systematic review of mortality in schizophrenia: is the differential mortality gap worsening over time? Arch Gen Psychiatry, 64(10), 1123-1131. doi:10.1001/archpsyc.64.10.1123

Secher, R. G., Hjorthoj, C. R., Austin, S. F., Thorup, A., Jeppesen, P., Mors, O., \& Nordentoft, M. (2015). Ten-year follow-up of the OPUS specialized early intervention trial for patients with a first episode of psychosis. Schizophr Bull, 41(3), 617-626. doi:10.1093/schbul/sbu155

Shiers, D., Jones, P. B., \& Field, S. (2009). Early intervention in psychosis: keeping the body in mind. Br J Gen Pract, 59(563), 395-396. doi:10.3399/bjgp09X420888

Singh, S. P., \& Fisher, H. L. (2004). A specialist early intervention for first-episode psychosis. Psychiatric Services, 55(8), 942-a-943. 
Singh, S. P., Grange, T., Vijaykrishnan, A., Francis, S., White, S., Fisher, H., . . Firn, M. (2007). One -year outcome of an early intervention in psychosis service: a naturalistic evaluation. Early Intervention in Psychiatry, 1(3), 282-287.

Spelman, L. M., Walsh, P. I., Sharifi, N., Collins, P., \& Thakore, J. H. (2007). Impaired glucose tolerance in first-episode drug-naive patients with schizophrenia. Diabet Med, 24(5), 481-485. doi:10.1111/j.1464-5491.2007.02092.x

Stubbs, B., Vancampfort, D., Firth, J., Hallgren, M., Schuch, F., Veronese, N., . . Koyanagi, A. (2018). Physical activity correlates among people with psychosis: Data from 47 low- and middle-income countries. Schizophr Res, 193, 412-417. doi:10.1016/j.schres.2017.06.025

Thorup, A., Petersen, L., Jeppesen, P., Ohlenschlaeger, J., Christensen, T., Krarup, G., . . Nordentoft, M. (2005). Integrated treatment ameliorates negative symptoms in first episode psychosis-results from the Danish OPUS trial. Schizophr Res, 79(1), 95-105. doi:10.1016/j.schres.2004.12.020

Tindall, R., Francey, S., \& Hamilton, B. (2015). Factors influencing engagement with case managers: Perspectives of young people with a diagnosis of first episode psychosis. International Journal of Mental Health Nursing, 24(4), 295-303. doi:http://dx.doi.org/10.1111/inm.12133

Tindall, R. M., Simmons, M. B., Allott, K., \& Hamilton, B. E. (2018). Essential ingredients of engagement when working alongside people after their first episode of psychosis: A qualitative meta-synthesis. Early Interv Psychiatry. doi:10.1111/eip.12566

Verma, S., Poon, L. Y., Lee, H., Rao, S., \& Chong, S. A. (2012). Evolution of early psychosis intervention services in Singapore. East Asian Archives of Psychiatry, 22(3), 114-117.

Wahlbeck, K., Westman, J., Nordentoft, M., Gissler, M., \& Laursen, T. M. (2011). Outcomes of Nordic mental health systems: life expectancy of patients with mental disorders. $\mathrm{Br} \mathrm{J}$ Psychiatry, 199(6), 453-458. doi:10.1192/bjp.bp.110.085100

Windell, D., \& Norman, R. M. G. (2012). A qualitative analysis of influences on recovery following a first episode of psychosis. International Journal of Social Psychiatry, 59(5), 493-500. doi:10.1177/0020764012443751

Wong, H. H., Yong, Y. H., Shahwan, S., Cetty, L., Vaingankar, J., Hon, C., . . Subramaniam, M. (2017). Case management in early psychosis intervention programme: Perspectives of clients and caregivers. Early Intervention in Psychiatry. doi:http://dx.doi.org/10.1111/eip.12534 


\begin{tabular}{|c|c|c|c|c|c|c|}
\hline 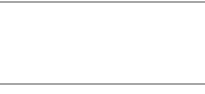 & $\begin{array}{l}\text { Program, } \\
\text { Country }\end{array}$ & $\begin{array}{l}\text { Author, } \\
\text { Year }\end{array}$ & $\begin{array}{l}\text { Study } \\
\text { Design }\end{array}$ & Population & Intervention, Control & Outcome Measures \\
\hline \multirow{5}{*}{ Quantitative } & \multirow{5}{*}{$\begin{array}{l}\text { OPUS, } \\
\text { Denmark }\end{array}$} & $\begin{array}{l}\text { Petersen et } \\
\text { al., 2005(a) }\end{array}$ & \multirow{5}{*}{$\begin{array}{c}\text { Randomized } \\
\text { controlled } \\
\text { trial }\end{array}$} & \multirow{5}{*}{$\begin{array}{l}\text { Patients } \\
\text { ( } \mathrm{n}=547) \text { with } \\
\text { first episode } \\
\text { of } \\
\text { schizophrenia } \\
\text { spectrum } \\
\text { disorder. }\end{array}$} & \multirow{5}{*}{$\begin{array}{l}\text { Intervention - Integrated } \\
\text { treatment (OPUS): } 2 \text { years; } \\
\text { Assertive community treatment } \\
\text { with programmes for family } \\
\text { involvement and social skills } \\
\text { training } \\
\text { Control - Standard treatment: } \\
\text { Offered contact with } \\
\text { a community mental health } \\
\text { centre }\end{array}$} & $\begin{array}{l}\text { Proportion of patients with poor clinical and social } \\
\text { outcome: } \\
\text { - } \quad \text { Psychotic and negative symptoms } \\
\text { - } \quad \text { Substance misuse } \\
\text { - } \quad \text { Global functioning } \\
\text { - } \quad \text { Housing } \\
\text { - } \quad \text { Employment/Education }\end{array}$ \\
\hline & & $\begin{array}{l}\text { Petersen et } \\
\text { al., 2005(b) }\end{array}$ & & & & 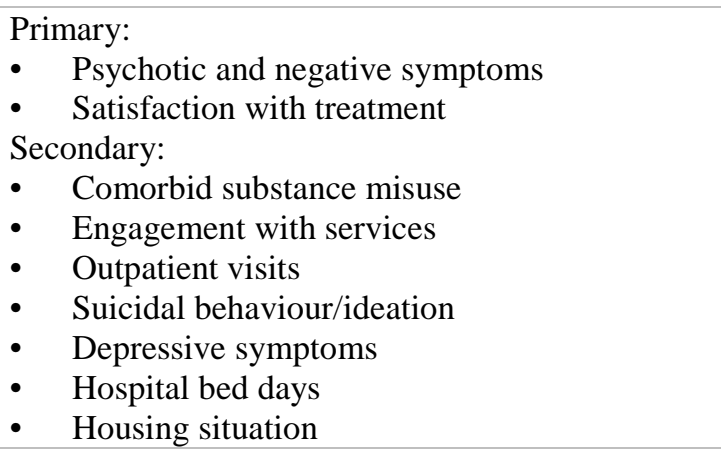 \\
\hline & & $\begin{array}{l}\text { Jeppesen et } \\
\text { al., } 2005\end{array}$ & & & & $\begin{array}{l}\text { - } \quad \text { Relatives' subjective burden of illness } \\
\text { - } \quad \text { Relatives' satisfaction with treatment }\end{array}$ \\
\hline & & $\begin{array}{l}\text { Thorup et } \\
\text { al., } 2005\end{array}$ & & & & $\begin{array}{ll}\text { - } & \text { Psychotic and negative symptoms } \\
\text { - } & \text { Disorganized symptoms }\end{array}$ \\
\hline & & $\begin{array}{l}\text { Bertelsen et } \\
\text { al., } 2008\end{array}$ & & & & $\begin{array}{l}\text { Primary: } \\
\text { - } \quad \text { Psychotic and negative symptoms } \\
\text { - } \quad \text { Global functioning } \\
\text { Secondary: } \\
\text { - } \quad \text { Hospital bed days }\end{array}$ \\
\hline
\end{tabular}


Lim et al.

\begin{tabular}{|c|c|c|c|c|c|}
\hline & & & & & $\begin{array}{ll}\text { - } & \text { Use of emergency department } \\
\text { - } & \text { Outpatient visits } \\
\text { - } & \text { Housing situation } \\
\text { - } & \text { Employment/Education } \\
\text { - } & \text { Symptom remission } \\
\text { - } & \text { Suicidal behaviour/ideation } \\
\text { - } & \text { Depressive symptoms }\end{array}$ \\
\hline & $\begin{array}{l}\text { Secher et } \\
\text { al., } 2015\end{array}$ & & & & $\begin{array}{l}\text { Primary: } \\
\text { - } \quad \text { Psychotic and negative symptoms } \\
\text { - } \quad \text { Global functioning } \\
\text { - } \quad \text { Suicidal behaviour/ideation } \\
\text { Secondary: } \\
\text { - Housing } \\
\text { - } \quad \text { Hospital bed days } \\
\text { - } \quad \text { Use of emergency department } \\
\end{array}$ \\
\hline $\begin{array}{l}\text { OPUS-II, } \\
\text { Denmark }\end{array}$ & $\begin{array}{l}\text { Albert et } \\
\text { al., } 2017\end{array}$ & $\begin{array}{l}\text { Randomized } \\
\text { controlled } \\
\text { trial }\end{array}$ & $\begin{array}{l}\text { Clients } \\
(n=400) \text { of } 6 \\
\text { OPUS teams } \\
\text { in Denmark }\end{array}$ & $\begin{array}{l}\text { Intervention - } 5 \text { years of } \\
\text { Specialized Early Intervention } \\
\text { (SEI; OPUS II); SEI: Modified } \\
\text { ACT, family involvement, } \\
\text { social skill training, patient- } \\
\text { case manager ratio of no more } \\
\text { than 12:1 } \\
\text { Control - } 2 \text { years of SEI + } 3 \\
\text { years of Treatment As Usual } \\
\text { (TAU); TAU: Referred to } \\
\text { community health centres }\end{array}$ & 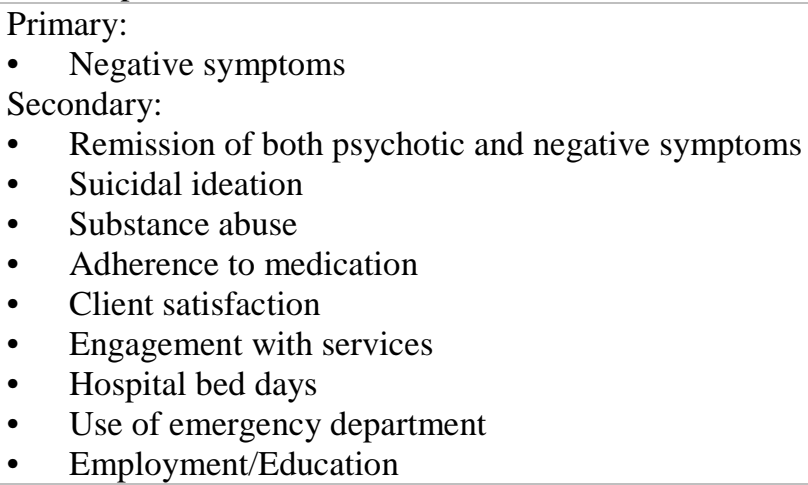 \\
\hline $\begin{array}{l}\text { TIPP- } \\
\text { Lausanne, } \\
\text { Switzerland }\end{array}$ & $\begin{array}{l}\text { Baumann et } \\
\text { al., } 2013\end{array}$ & $\begin{array}{l}\text { Retrospective } \\
\text { cohort study }\end{array}$ & $\begin{array}{l}\text { Clients } \\
(\mathrm{n}=350) \text { of } \\
\text { TIPP- }\end{array}$ & $\begin{array}{l}\text { Intervention - Comprehensive } \\
\text { 3-year programme composed } \\
\text { of an outpatient clinic based on }\end{array}$ & $\begin{array}{ll}\text { - } & \text { Service disengagement rate } \\
\text { - } & \text { Hospital admissions }\end{array}$ \\
\hline
\end{tabular}


Lim et al.

\begin{tabular}{|c|c|c|c|c|c|}
\hline & & & Lausanne & $\begin{array}{l}\text { ACM, a specialised inpatient } \\
\text { unit, and an intensive mobile } \\
\text { team } \\
\text { Control - TAU prior to } \\
\text { implementation of TIPP- } \\
\text { Lausanne }\end{array}$ & \\
\hline $\begin{array}{l}\text { PEPP, } \\
\text { Canada }\end{array}$ & $\begin{array}{l}\text { Malla et al., } \\
2017\end{array}$ & $\begin{array}{l}\text { Randomized } \\
\text { controlled } \\
\text { trial }\end{array}$ & $\begin{array}{l}\text { Clients } \\
(\mathrm{n}=220) \text { of } \\
\text { EIS in } \\
\text { Montreal }\end{array}$ & $\begin{array}{l}\text { Intervention - } 5 \text { years of EIS; } \\
\text { EIS: Case management, family } \\
\text { intervention, cognitive } \\
\text { behavioural therapy (CBT), } \\
\text { crisis intervention } \\
\text { Control - } 2 \text { years of EIS } \\
\text { followed by } 3 \text { years of regular } \\
\text { care; Regular care: Transfer to } \\
\text { primary or secondary care }\end{array}$ & 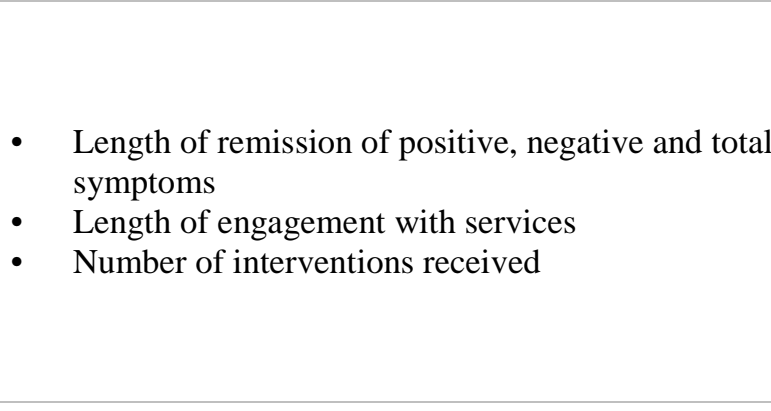 \\
\hline \multirow[t]{2}{*}{$\begin{array}{l}\text { J-CAP, } \\
\text { Japan }\end{array}$} & $\begin{array}{l}\text { Ando et al., } \\
2013\end{array}$ & $\begin{array}{l}\text { Retrospective } \\
\text { cohort study }\end{array}$ & $\begin{array}{l}\text { FEP patients } \\
(n=30)\end{array}$ & $\begin{array}{l}\text { Intervention - } \\
\text { Multidisciplinary team } \\
\text { intervention: Case manager } \\
\text { with at least monthly contact, } \\
\text { assists with social participation } \\
\text { and clinical recovery using } \\
\text { psychosocial and } \\
\text { pharmacological therapy } \\
\text { Control - TAU }\end{array}$ & $\begin{array}{ll}\text { - } & \text { Service disengagement rate } \\
\text { - } & \text { Functional remission - Vocational functioning }\end{array}$ \\
\hline & $\begin{array}{l}\text { Nishida et } \\
\text { al., } 2018\end{array}$ & $\begin{array}{l}\text { Randomized } \\
\text { controlled } \\
\text { trial }\end{array}$ & $\begin{array}{l}\text { FEP patients } \\
(n=77)\end{array}$ & $\begin{array}{l}\text { Intervention - } 18 \text { months of } \\
\text { specialised comprehensive EIS } \\
\text { care: Trained case managers } \\
\text { delivered various psychosocial }\end{array}$ & $\begin{array}{l}\text { Primary: } \\
\text { - Social and vocational functioning } \\
\text { Secondary: } \\
\text { - Treatment dropout rate }\end{array}$ \\
\hline
\end{tabular}


Lim et al.

\begin{tabular}{|c|c|c|c|c|c|}
\hline & & & & $\begin{array}{l}\text { interventions } \\
\text { Control - Standard care: } \\
\text { Hospital outpatient care with } \\
\text { no trained case managers }\end{array}$ & $\begin{array}{ll}\text { - } & \text { Symptom remission } \\
\text { - } & \text { Quality of life } \\
\text { - } & \text { Education and vocational recovery } \\
\text { - } & \text { Satisfaction with care of participants and families }\end{array}$ \\
\hline \multirow{2}{*}{$\begin{array}{l}\text { ETHOS, } \\
\text { England }\end{array}$} & $\begin{array}{l}\text { Singh and } \\
\text { Fisher, } \\
\text { 2004, } \\
\text { England }\end{array}$ & $\begin{array}{l}\text { Retrospective } \\
\text { cohort study }\end{array}$ & $\begin{array}{l}\text { Clients of } \\
\text { ETHOS and } \\
\text { clients of } \\
\text { Community } \\
\text { Mental } \\
\text { Health } \\
\text { Teams }\end{array}$ & $\begin{array}{l}\text { Intervention - ETHOS care } \\
\text { Control - Standard care } \\
\text { delivered by generic services }\end{array}$ & $\begin{array}{ll}\text { - } & \text { Inpatient stays } \\
\text { - } & \text { Frequency of contact with care coordinators }\end{array}$ \\
\hline & $\begin{array}{l}\text { Singh et al., } \\
2007\end{array}$ & $\begin{array}{l}\text { Prospective } \\
\text { cohort study }\end{array}$ & $\begin{array}{l}\text { Clients } \\
(\mathrm{n}=129) \text { of } \\
\text { ETHOS }\end{array}$ & $\begin{array}{l}\text { Intervention - ETHOS care: } 2 \\
\text { years of community-based care } \\
\text { delivered by a multidisciplinary } \\
\text { team; care coordinator with } \\
\text { max caseload of } 12 \text { patients, } \\
\text { and various psychosocial and } \\
\text { pharmacological interventions }\end{array}$ & $\begin{array}{ll}\text { - } & \text { Psychotic and negative symptoms } \\
\text { - } & \text { Functioning } \\
\text { - } & \text { Substance misuse } \\
\text { - } & \text { Hospucation/Training/Employment admissions } \\
\text { - } & \text { Inpatient days }\end{array}$ \\
\hline $\begin{array}{l}\text { GET UP } \\
\text { PIANO, } \\
\text { Italy }\end{array}$ & $\begin{array}{l}\text { Ruggeri et } \\
\text { al., } 2015\end{array}$ & $\begin{array}{l}\text { Randomized } \\
\text { controlled } \\
\text { trial }\end{array}$ & $\begin{array}{l}\text { FEP patients } \\
(\mathrm{n}=444) \text { of } \\
\text { community } \\
\text { mental health } \\
\text { centres }\end{array}$ & $\begin{array}{l}\text { Intervention - Integrated multi- } \\
\text { element psychosocial } \\
\text { intervention, adjunctive to } \\
\text { TAU: CBT to patients, family } \\
\text { intervention to families, and } \\
\text { case management to both } \\
\text { Control - TAU: } \\
\text { Psychopharmacological } \\
\text { treatment, non-supportive } \\
\text { clinical management, non- } \\
\text { specific informal family }\end{array}$ & $\begin{array}{l}\text { Primary: } \\
\text { - } \quad \text { Psychotic and negative symptoms } \\
\text { - } \quad \text { Days of hospitalization } \\
\text { Secondary: } \\
\text { - } \quad \text { Subjective appraisal of psychotic symptoms } \\
\text { - } \quad \text { Global functioning } \\
\text { - } \quad \text { Emotional well-being - Depressive symptoms } \\
\text { - Service disengagement rates }\end{array}$ \\
\hline
\end{tabular}


Lim et al.

\begin{tabular}{|c|c|c|c|c|c|}
\hline & & & & support sessions & \\
\hline \multirow{2}{*}{$\begin{array}{l}\text { EASY, } \\
\text { Hong Kong }\end{array}$} & $\begin{array}{l}\text { Chen et al., } \\
2011\end{array}$ & $\begin{array}{c}\text { Historical } \\
\text { control study }\end{array}$ & $\begin{array}{l}\text { Clients } \\
(\mathrm{n}=700) \text { of } \\
\text { EASY } \\
\text { programme } \\
\text { and clients } \\
(\mathrm{n}=700) \text { of } \\
\text { standard care }\end{array}$ & $\begin{array}{l}\text { Intervention - EASY } \\
\text { programme delivered by } \\
\text { specialised teams: Case } \\
\text { management approach where } \\
\text { case managers provided } \\
\text { various psychosocial } \\
\text { interventions } \\
\text { Control - Standard care }\end{array}$ & $\begin{array}{ll}\text { - } & \text { Psychotic and negative symptoms } \\
\text { - } & \text { Relapse rate } \\
\text { - } & \text { Social and vocational functioning } \\
\text { - } & \text { Employment/Education } \\
\text { - } & \text { Suicidal behaviour/ideation } \\
\text { - } & \text { Hospital admissions } \\
\text { - } & \text { Entpatient service use } \\
\end{array}$ \\
\hline & $\begin{array}{l}\text { Chang et } \\
\text { al., } 2015\end{array}$ & $\begin{array}{l}\text { Randomized } \\
\text { controlled } \\
\text { trial }\end{array}$ & $\begin{array}{l}\text { Clients } \\
(\mathrm{n}=160) \text { of } \\
\text { EASY } \\
\text { programme }\end{array}$ & $\begin{array}{l}\text { Intervention - 3-year EIS care: } \\
\text { Additional year of case } \\
\text { management } \\
\text { Control - 2-year EIS care } \\
\text { followed by step-down care: } \\
\text { Out-patient medical follow-up } \\
\text { with limited community } \\
\text { support }\end{array}$ & 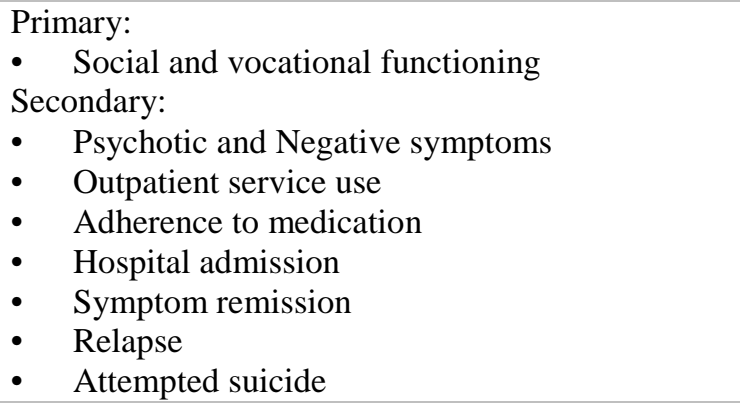 \\
\hline \multirow[t]{2}{*}{$\begin{array}{l}\text { EPIP, } \\
\text { Singapore }\end{array}$} & $\begin{array}{l}\text { Chong et } \\
\text { al., } 2006\end{array}$ & $\begin{array}{l}\text { Retrospective } \\
\text { cohort study }\end{array}$ & $\begin{array}{l}\text { Clients } \\
(\mathrm{n}=87) \text { of } \\
\text { EPIP and } \\
\text { clients } \\
(\mathrm{n}=50) \text { of the } \\
\text { Institute of } \\
\text { Mental } \\
\text { Health pre- } \\
\text { EPIP }\end{array}$ & $\begin{array}{l}\text { Intervention - EPIP: Care } \\
\text { delivered by a multidisciplinary } \\
\text { team based on the case } \\
\text { management model } \\
\text { Control - Standard treatment } \\
\text { prior to inception of EPIP }\end{array}$ & $\begin{array}{l}\text { Adherence to process indicators: Indicators for } \\
\text { assessment (3), Indicators for medical treatment ( } 7 \text { ), } \\
\text { Indicators for continuity of care (3) }\end{array}$ \\
\hline & $\begin{array}{l}\text { Verma et } \\
\text { al., } 2012\end{array}$ & $\begin{array}{l}\text { Prospective } \\
\text { cohort study }\end{array}$ & $\begin{array}{l}\text { Clients } \\
(n=284) \text { of }\end{array}$ & Intervention - EPIP & $\begin{array}{l}\text { - } \quad \text { Psychotic and negative symptoms } \\
\text { - } \quad \text { Global functioning }\end{array}$ \\
\hline
\end{tabular}


Lim et al.

\begin{tabular}{|c|c|c|c|c|c|c|}
\hline & & & & the EPIP & & $\begin{array}{ll}\text { - } & \text { Satisfaction with treatment } \\
\text { - } & \text { Suicide rate }\end{array}$ \\
\hline & $\begin{array}{l}\text { OPUS, } \\
\text { Denmark } \\
\text { EASY, } \\
\text { Hong Kong } \\
\text { Programme } \\
\text { 2000, Italy } \\
\text { LEO, } \\
\text { England } \\
\text { Parachute, } \\
\text { Sweden } \\
\text { PEPP, } \\
\text { Canada } \\
\text { EPPIC, } \\
\text { Australia } \\
\text { EPP, } \\
\text { Australia } \\
\text { ETHOS, } \\
\text { England }\end{array}$ & $\begin{array}{l}\text { Randall et } \\
\text { al., } 2015\end{array}$ & $\begin{array}{l}\text { Meta- } \\
\text { analysis }\end{array}$ & $\begin{array}{l}\text { Clients of } \\
\text { EIS }\end{array}$ & $\begin{array}{l}\text { Intervention - EIS care: Multi- } \\
\text { disciplinary staff using ACM to } \\
\text { engage in multi-modal } \\
\text { treatments } \\
\text { Control - TAU }\end{array}$ & $\begin{array}{ll}\text { - } & \text { Hospital bed days } \\
\text { - } & \text { Hospital admission }\end{array}$ \\
\hline & $\begin{array}{l}\text { PEPP, } \\
\text { Canada }\end{array}$ & $\begin{array}{l}\text { Anderson } \\
\text { et al., } 2018\end{array}$ & $\begin{array}{l}\text { Retrospective } \\
\text { cohort study }\end{array}$ & $\begin{array}{l}\text { Clients } \\
(n=530) \text { of } \\
\text { and Non- } \\
\text { clients } \\
(n=992) \text { of } \\
\text { EPI }\end{array}$ & $\begin{array}{l}\text { Intervention - EPI care: Team- } \\
\text { based, coordinated specialty } \\
\text { care with an assertive case- } \\
\text { management approach }\end{array}$ & $\begin{array}{ll}\text { - } & \text { Access to psychiatric services } \\
\text { - } & \text { Use of emergency department } \\
\text { - } & \text { All-cause mortality } \\
\text { - } & \text { Use of primary care } \\
\text { - } & \text { Suicidal behaviour/ideation }\end{array}$ \\
\hline Qualitative & $\begin{array}{l}\text { Australia, } \\
\text { England, } \\
\text { United } \\
\text { States }\end{array}$ & $\begin{array}{l}\text { Tindall et } \\
\text { al., } 2017\end{array}$ & $\begin{array}{l}\text { Qualitative } \\
\text { Meta- } \\
\text { synthesis }\end{array}$ & $\begin{array}{l}\text { Clients } \\
(\mathrm{n}=192) \text { of } \\
\text { EIS and their } \\
\text { caregivers } \\
(\mathrm{n}=43)\end{array}$ & N.A. & - How engagement is experienced within the EIS \\
\hline
\end{tabular}


Lim et al.

\begin{tabular}{|c|c|c|c|c|c|}
\hline $\begin{array}{l}\text { EPIP, } \\
\text { Singapore }\end{array}$ & $\begin{array}{l}\text { Wong et } \\
\text { al., } 2017\end{array}$ & $\begin{array}{l}\text { Cross- } \\
\text { sectional } \\
\text { study }\end{array}$ & $\begin{array}{l}\text { Clients } \\
(n=49) \text { of } \\
\text { EIS and their } \\
\text { caregivers } \\
(n=19)\end{array}$ & N.A. & $\begin{array}{l}\text { - Perspectives on case management provided by the } \\
\text { EIS }\end{array}$ \\
\hline $\begin{array}{l}\text { EPPIC., } \\
\text { Australia }\end{array}$ & $\begin{array}{l}\text { Tindall et } \\
\text { al., } 2015\end{array}$ & $\begin{array}{l}\text { Cross- } \\
\text { sectional } \\
\text { study }\end{array}$ & $\begin{array}{l}\text { Clients }(n=7) \\
\text { of EIS }\end{array}$ & N.A. & $\begin{array}{l}\text { - } \quad \text { Perspectives of factors influencing young people’s } \\
\text { engagement with case managers }\end{array}$ \\
\hline $\begin{array}{l}\text { JCEP, } \\
\text { Hong Kong }\end{array}$ & $\begin{array}{l}\text { Lai et al., } \\
2013\end{array}$ & Case report & $\begin{array}{l}\text { Client }(n=1) \\
\text { of EIS }\end{array}$ & N.A. & $\begin{array}{l}\text { - How case management improved outcomes of a FEP } \\
\text { patient }\end{array}$ \\
\hline $\begin{array}{l}\text { National } \\
\text { EDEN, } \\
\text { England }\end{array}$ & $\begin{array}{l}\text { Lester et } \\
\text { al., } 2012\end{array}$ & $\begin{array}{l}\text { Longitudinal } \\
\text { study }\end{array}$ & $\begin{array}{l}\text { Clients } \\
(n=21) \text { of } \\
\text { EIS }\end{array}$ & N.A. & $\begin{array}{l}\text { Service users’ perspective of EIS and primary care, } \\
\text { in-depth and over time }\end{array}$ \\
\hline $\begin{array}{l}\text { PEPP, } \\
\text { Canada }\end{array}$ & $\begin{array}{l}\text { Windell } \\
\text { and } \\
\text { Norman, } \\
2012\end{array}$ & $\begin{array}{l}\text { Cross- } \\
\text { sectional } \\
\text { study }\end{array}$ & $\begin{array}{l}\text { Clients } \\
(n=30) \text { of } \\
\text { EIS }\end{array}$ & N.A. & $\begin{array}{l}\text { - Critical factors perceived as helpful and harmful in } \\
\text { recovery }\end{array}$ \\
\hline $\begin{array}{l}\text { PEPP, } \\
\text { Canada }\end{array}$ & $\begin{array}{l}\text { Lal et al., } \\
2017\end{array}$ & $\begin{array}{l}\text { Cross- } \\
\text { sectional } \\
\text { study }\end{array}$ & $\begin{array}{l}\text { Youths } \\
(n=17) \text { with } \\
\text { FEP }\end{array}$ & N.A. & $\begin{array}{l}\text { - How mental health and related services support and } \\
\text { hinder resilience in young FEP patients }\end{array}$ \\
\hline
\end{tabular}

Table 2. Summary of themes and outcomes explored

\begin{tabular}{|c|c|c|c|c|}
\hline \multicolumn{2}{|r|}{ Key Worker-Mediated Outcome } & Studies Measuring Outcome & Outcome achieved (Y/N) & Number of studies \\
\hline \multirow[t]{2}{*}{$\begin{array}{l}\text { Influences on } \\
\text { Lifestyle }\end{array}$} & Reduced Co-Morbid Substance Misuse & $\begin{array}{c}\text { Petersen et al., 2005(a) } \\
\text { Petersen et al., 2005(b) } \\
\text { Singh et al., 2007 } \\
\text { Bertelsen et al., } 2008 \\
\text { Albert et al., } 2017\end{array}$ & $\begin{array}{l}\mathrm{Y} \\
\mathrm{Y} \\
\mathrm{N} \\
\mathrm{N} \\
\mathrm{N}\end{array}$ & $\begin{array}{c}\mathrm{Y}: 2 \\
\mathrm{~N}: 3 \\
\text { Total: } 5\end{array}$ \\
\hline & Enhanced engagement in discussions on physical health & Wong et al., 2017 & $\mathrm{Y}$ & $Y: 1$ \\
\hline
\end{tabular}




\begin{tabular}{|c|c|c|c|c|c|}
\hline & & & Lester et al., 2012 & $\mathrm{~N}$ & $\begin{array}{c}\text { N: } 1 \\
\text { Total: } 2\end{array}$ \\
\hline \multirow{5}{*}{$\begin{array}{l}\text { Influences on } \\
\text { Effects of } \\
\text { Psychosis }\end{array}$} & \multirow{5}{*}{$\begin{array}{l}\text { Enhanced } \\
\text { symptomatic } \\
\text { recovery }\end{array}$} & $\begin{array}{c}\text { Reduced severity of psychotic and negative } \\
\text { symptoms } \\
\text { (SAPS, SANS, BPRS, CGI-S) }\end{array}$ & $\begin{array}{c}\text { Petersen et al., 2005(a) } \\
\text { Petersen et al., 2005(b) } \\
\text { Thorup et al., 2005 } \\
\text { Singh et al., 2007 } \\
\text { Ruggeri et al., } 2015 \\
\text { Chen et al., } 2011 \\
\text { Chang et al., } 2015 \\
\text { Verma et al., } 2012 \\
\text { Windell and Norman, } 2012 \\
\text { Bertelsen et al., } 2008 \\
\text { Secher et al., } 2015 \\
\text { Albert et al., } 2017\end{array}$ & $\begin{array}{c}\text { Y } \\
\text { Y } \\
\text { Y } \\
\text { Y } \\
\text { Y } \\
\text { Y } \\
\text { Y } \\
\text { Y } \\
\text { Y } \\
\text { Y (Negative), N (Psychotic) } \\
\text { N }\end{array}$ & $\begin{array}{l}\text { Y: } 9 \\
\text { Y/N: } 1 \\
\text { N: } 2 \\
\text { Total: } 12\end{array}$ \\
\hline & & $\begin{array}{c}\text { Enhanced rate of symptom remission } \\
\text { (PANSS, SAPS, SANS, PSYRATS, CGI-S) }\end{array}$ & $\begin{array}{c}\text { Chen et al., } 2011 \\
\text { Malla et al., } 2017 \\
\text { Nishida et al., } 2018 \\
\text { Bertelsen et al., } 2008 \\
\text { Chang et al., } 2015 \\
\text { Albert et al., } 2017\end{array}$ & $\begin{array}{l}\mathrm{Y} \\
\mathrm{Y} \\
\mathrm{Y} \\
\mathrm{N} \\
\mathrm{N} \\
\mathrm{N}\end{array}$ & $\begin{array}{c}\text { Y: } 3 \\
\text { N: } 3 \\
\text { Total: } 6\end{array}$ \\
\hline & & Reduced rate of relapse & $\begin{array}{l}\text { Tindall et al., } 2015 \\
\text { Chen et al., } 2011 \\
\text { Chang et al., } 2015\end{array}$ & $\begin{array}{l}\mathrm{Y} \\
\mathrm{N} \\
\mathrm{N}\end{array}$ & $\begin{array}{c}\text { Y: } 1 \\
\text { N: } 2 \\
\text { Total: } 3\end{array}$ \\
\hline & & $\begin{array}{l}\text { Enhanced global functioning } \\
\text { (GAF) }\end{array}$ & $\begin{array}{l}\text { Petersen et al., 2005(a) } \\
\text { Singh et al., } 2007 \\
\text { Verma et al., } 2012 \\
\text { Ruggeri et al., } 2015 \\
\text { Bertelsen et al., } 2008 \\
\text { Secher et al., } 2015\end{array}$ & $\begin{array}{l}\mathrm{Y} \\
\mathrm{Y} \\
\mathrm{Y} \\
\mathrm{Y} \\
\mathrm{N} \\
\mathrm{N}\end{array}$ & $\begin{array}{c}\mathrm{Y}: 4 \\
\mathrm{~N}: 2 \\
\text { Total: } 6\end{array}$ \\
\hline & & $\begin{array}{l}\text { Reduced depressive symptoms } \\
\text { (ICD-10, HAM-D, CDS) }\end{array}$ & $\begin{array}{l}\text { Chang et al., } 2015 \\
\text { Ruggeri et al., } 2015\end{array}$ & $\begin{array}{l}\mathrm{Y} \\
\mathrm{Y}\end{array}$ & $\begin{array}{l}Y: 2 \\
N: 2\end{array}$ \\
\hline
\end{tabular}


Chen et al., 2011

Verma et al., 2012

Petersen et al., 2005(b)

Reduced suicidal behaviour/ideation

Bertelsen et al.,2008

Chang et al., 2015

Secher et al., 2015

Albert et al., 2017

Anderson et al., 2018

Lester et al., 2012

Enhanced practical and/or emotional support

Windell and Norman, 2012

Tindall et al., 2015

Lal et al., 2017

Wong et al, 2017

Lester et al., 2012

Enhanced social participation

Windell and Norman, 2012

Petersen et al., 2005(a)

Singh et al., 2007

Enhanced Enhanced social and vocational functioning

and/or employment status

(GAF-F, SOFAS, RFS,

outcomes

Employment/Education)

Chen et al., 2011

Chang et al., 2015

Ando et al., 2013

Bertelsen et al., 2008

Albert et al., 2017

Nishida et al., 2018

Petersen et al., 2005(a)

Enhanced independence

Bertelsen et al., 2008

Secher et al., 2015

Petersen et al., 2005(b)

Reduced relatives' burden of illness

Jeppesen et al., 2005

\begin{tabular}{|c|c|}
\hline N & Total: 4 \\
\hline Y & \\
\hline Y & \\
N & \\
N & Y: 2 \\
N & N: 6 \\
N & Total: 8 \\
N & \\
N & \\
\hline Y & \\
Y & \\
Y & Y: 5 \\
Y & Total: 5 \\
Y & \\
\hline Y & Y: 2 \\
Y & Total: 2 \\
\hline Y & \\
Y & \\
Y & Y: 5 \\
Y & N: 3 \\
Y & Total: 8 \\
N & \\
N & \\
N & Total: 1 \\
\hline Y & Y: 3 1 \\
Y & Total: 4 \\
Y & \\
N & \\
Y & \\
\hline & \\
\hline
\end{tabular}




\begin{tabular}{|c|c|c|c|c|c|}
\hline & \multirow{5}{*}{$\begin{array}{l}\text { Enhanced } \\
\text { illness } \\
\text { management }\end{array}$} & $x^{2}$ & $\begin{array}{l}\text { Singh and Fisher, } 2004 \\
\text { Petersen et al., 2005(b) } \\
\text { Bertelsen et al., } 2008 \\
\text { Chen et al, } 2011 \\
\text { Baumann et al., } 2013 \\
\text { Randall et al., } 2015 \\
\text { Singh et al., } 2007 \\
\text { Ando et al., } 2013 \\
\text { Ruggeri et al., } 2015 \\
\text { Secher et al., } 2015 \\
\text { Chang et al., } 2015 \\
\text { Albert et al., } 2017 \\
\text { Anderson et al., } 2018\end{array}$ & $\begin{array}{l}\mathrm{Y} \\
\mathrm{Y} \\
\mathrm{Y} \\
\mathrm{Y} \\
\mathrm{Y} \\
\mathrm{Y} \\
\mathrm{N} \\
\mathrm{N} \\
\mathrm{N} \\
\mathrm{N} \\
\mathrm{N} \\
\mathrm{N} \\
\mathrm{N}\end{array}$ & $\begin{array}{c}\text { Y: } 6 \\
\text { N: } 7 \\
\text { Total: } 13\end{array}$ \\
\hline & & Reduced emergency department visits & $\begin{array}{l}\text { Anderson et al., } 2018 \\
\text { Bertelsen et al., } 2008 \\
\text { Secher et al., } 2015 \\
\text { Albert et al., } 2017\end{array}$ & $\begin{array}{c}\text { Y (2-year), N (5-year) } \\
\text { N } \\
\text { N } \\
N\end{array}$ & $\begin{array}{l}\text { Y/N: } 1 \\
\text { N: } 3 \\
\text { Total: } 4\end{array}$ \\
\hline & & $\begin{array}{l}\text { Enhanced education on illness and } \\
\text { management strategies }\end{array}$ & $\begin{array}{c}\text { Chong et al., } 2006 \\
\text { Lester et al., } 2012 \\
\text { Windell and Norman, } 2012 \\
\text { Lai et al., 2013 } \\
\text { Tindall et al., } 2015 \\
\text { Wong et al., } 2017\end{array}$ & $\begin{array}{l}\mathrm{Y} \\
\mathrm{Y} \\
\mathrm{Y} \\
\mathrm{Y} \\
\mathrm{Y} \\
\mathrm{Y}\end{array}$ & $\begin{array}{c}\text { Y: } 6 \\
\text { Total: } 6\end{array}$ \\
\hline & & Enhanced adherence to medication & $\begin{array}{l}\text { Chang et al., } 2015 \\
\text { Albert et al., } 2017\end{array}$ & $\begin{array}{l}\mathrm{N} \\
\mathrm{N}\end{array}$ & $\begin{array}{c}\text { N: } 2 \\
\text { Total: } 2\end{array}$ \\
\hline & & Enhanced crisis management & Wong et al., 2017 & $\mathrm{Y}$ & $\begin{array}{c}\text { Y: } 1 \\
\text { Total: } 1\end{array}$ \\
\hline $\begin{array}{l}\text { Influences on } \\
\text { Organization } \\
\text { al Barriers }\end{array}$ & $\begin{array}{l}\text { Enhanced } \\
\text { continuity of } \\
\text { care }\end{array}$ & Enhanced engagement with services & $\begin{array}{l}\text { Singh and fisher, } 2004 \\
\text { Petersen et al., 2005(b) } \\
\text { Chong et al., } 2006 \\
\text { Chen et al., } 2011\end{array}$ & $\begin{array}{l}\mathrm{Y} \\
\mathrm{Y} \\
\mathrm{Y} \\
\mathrm{Y}\end{array}$ & $\begin{array}{c}\mathrm{Y}: 11 \\
\mathrm{~N}: 1 \\
\text { Total: } 12\end{array}$ \\
\hline
\end{tabular}


Ando et al., 2013

Baumann et al., 2013

Tindall et al., 2015

Albert et al., 2017

Malla et al., 2017

Tindall et al., 2017

Nishida et al., 2018

Ruggeri et al., 2015

Petersen et al., 2005(b)

Chong et al., 2006

Chen et al., 2011

Increased outpatient service use

Chang et al., 2015

Albert et al., 2017

Bertelsen et al., 2008

Secher et al., 2015

Chong et al., 2006

Wong et al., 2017

Enhanced health assessments/monitoring

Enhanced collaboration with other care providers

Lester et al., 2012

Wong et al., 2017

Petersen et al., 2005(b)

Lester et al., 2012

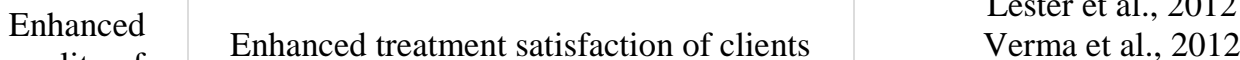

quality of

care

Enhanced treatment satisfaction of caregivers

Albert et al., 2017

Nishida et al., 2018

Jeppesen et al., 2005

Nishida et al., 2018

Chong et al., 2006

Malla et al., 2017

Malla et al., 2017

Enhanced

access to

Greater number of interventions received

Anderson et al., 2018

\begin{tabular}{|c|c|}
\hline $\begin{array}{l}\mathrm{Y} \\
\mathrm{Y} \\
\mathrm{Y} \\
\mathrm{Y} \\
\mathrm{Y} \\
\mathrm{Y} \\
\mathrm{Y}\end{array}$ & \\
\hline $\begin{array}{l}\mathrm{Y} \\
\mathrm{Y} \\
\mathrm{Y} \\
\mathrm{Y} \\
\mathrm{Y} \\
\mathrm{N}\end{array}$ & $\begin{array}{c}\mathrm{Y}: 5 \\
\mathrm{~N}: 2 \\
\text { Total: } 7\end{array}$ \\
\hline $\begin{array}{l}\mathrm{Y} \\
\mathrm{Y} \\
\mathrm{Y} \\
\mathrm{Y}\end{array}$ & $\begin{array}{c}\text { Y: } 2 \\
\text { Total: } 2 \\
\text { Y: } 2 \\
\text { Total: } 2\end{array}$ \\
\hline $\begin{array}{l}Y \\
Y \\
Y \\
Y \\
N\end{array}$ & $\begin{array}{c}\mathrm{Y}: 4 \\
\mathrm{~N}: 1 \\
\text { Total: } 5\end{array}$ \\
\hline$N$ & $\begin{array}{c}\text { Y:1 } \\
\text { N: } 1 \\
\text { Total: } 2\end{array}$ \\
\hline $\begin{array}{l}\mathrm{Y} \\
\mathrm{Y}\end{array}$ & $\begin{array}{c}\mathrm{Y}: 2 \\
\text { Total: } 2\end{array}$ \\
\hline $\begin{array}{l}Y \\
Y\end{array}$ & $\begin{array}{c}\text { Y: } 2 \\
\text { Total: } 2\end{array}$ \\
\hline
\end{tabular}


Lim et al.

Table 3. Studies excluded due to no full-text access

\begin{tabular}{|c|c|c|}
\hline Authors & Title & Journal \\
\hline Tuomola, 2017 & $\begin{array}{l}\text { From the blind leading the blind to leading from one step } \\
\text { behind: Experiences with running a solution-focused } \\
\text { supervision group for case managers }\end{array}$ & Solution Focused Practice in Asia \\
\hline Chen et al., 2016 & Activity intervention for first-episode psychosis & Interventions for Mental Health \\
\hline Gates et al., 2015 & $\begin{array}{l}\text { Mental health starts with physical health: current status and } \\
\text { future directions of non-pharmacological interventions to } \\
\text { improve physical health in first-episode psychosis }\end{array}$ & The Lancet Psychiatry \\
\hline Curtis et al., 2011 & $\begin{array}{l}\text { Metabolic complications in first episode psychosis: Defining the } \\
\text { issues, neural substrates and developing an effective early } \\
\text { intervention framework }\end{array}$ & $\begin{array}{l}\text { Australian and New Zealand } \\
\text { Journal of Psychiatry }\end{array}$ \\
\hline Curtis et al., 2011 & $\begin{array}{l}\text { Positive cardiometabolic health: An early intervention } \\
\text { framework for patients on psychotropic medications }\end{array}$ & Early Intervention in Psychiatry \\
\hline Burns, 2010 & $\begin{array}{l}\text { Modern Community Care Strategies for Schizophrenia Care: } \\
\text { Impacts on Outcome }\end{array}$ & $\begin{array}{l}\text { Advances in Schizophrenia } \\
\text { Research }\end{array}$ \\
\hline Edwards, 1999 & Preventive case management in first-episode psychosis & Book \\
\hline DeQuardo, 1998 & $\begin{array}{l}\text { Pharmacologic treatment of first-episode schizophrenia: early } \\
\text { intervention is key to outcome }\end{array}$ & The Journal of clinical psychiatry \\
\hline McGorry, 1998 & Suicide in early psychosis: Could early intervention work? & $\begin{array}{l}\text { Suicide prevention: The global } \\
\text { context. }\end{array}$ \\
\hline $\begin{array}{l}\text { Aberg-Wistedt et } \\
\text { al., } 1995\end{array}$ & $\begin{array}{l}\text { Two-year outcome of team-based intensive case management } \\
\text { for patients with schizophrenia. }\end{array}$ & Psychiatric services \\
\hline $\begin{array}{l}\text { Dende and Kline, } \\
1995\end{array}$ & $\begin{array}{l}\text { Overcoming, crack, schizophrenia, and homelessness: A } \\
\text { comprehensive case management approach }\end{array}$ & $\begin{array}{l}\text { New directions for mental health } \\
\text { services }\end{array}$ \\
\hline Prendergast, 1995 & $\begin{array}{l}\text { Psychiatric rehabilitation and case management in } \\
\text { schizophrenia }\end{array}$ & $\begin{array}{l}\text { Contemporary issues in the } \\
\text { treatment of Schizophrenia }\end{array}$ \\
\hline $\begin{array}{l}\text { Hornstra et al., } \\
1993\end{array}$ & $\begin{array}{l}\text { The effect of intensive case management on hospitalization of } \\
\text { patients with schizophrenia }\end{array}$ & Psychiatric Services \\
\hline
\end{tabular}


Lim et al.

This article is protected by copyright. All rights reserved. 
Figure 2. Flow of identification, screening, eligibility and inclusion

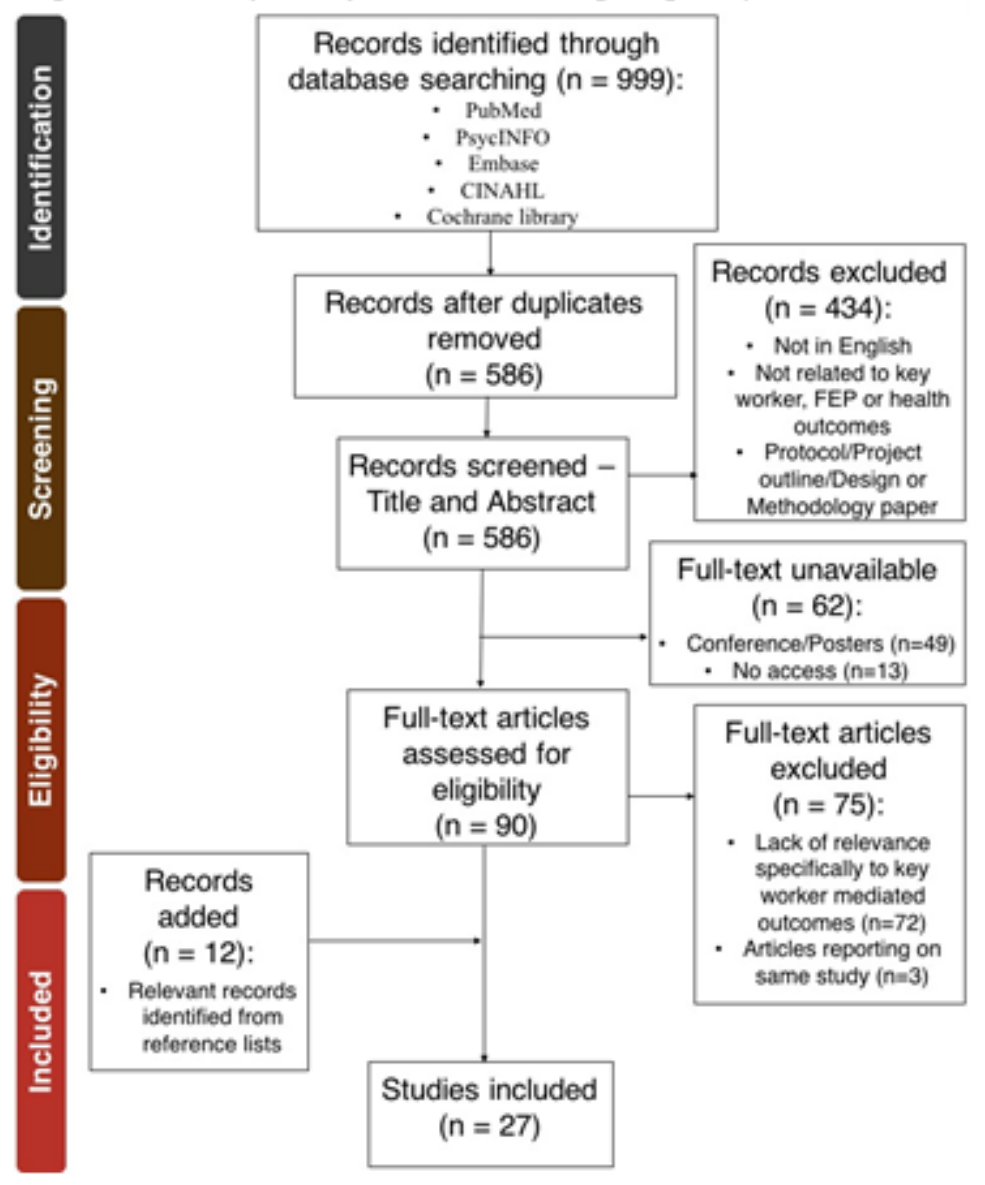

EIP_12937_Figure 2.tif

This article is protected by copyright. All rights reserved. 
Figure 3. Factors contributing to poorer physical health outcomes in FEP

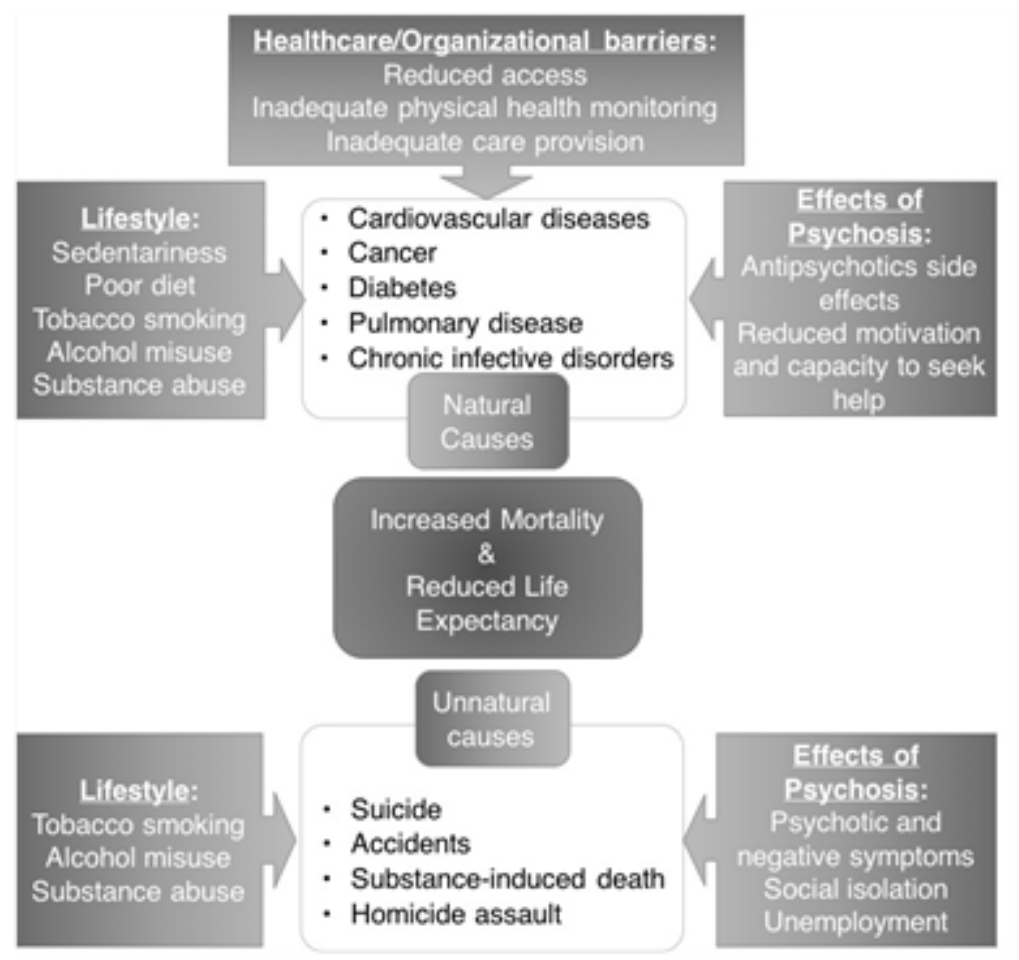

EIP_12937_Figure 3.tif

This article is protected by copyright. All rights reserved. 
Keywords and combinations thereof:

1. Key worker

2. Case manage*

3. Care coordinat*

4. Early intervention

5. First episode psychosis

6. Early psychosis

7. Recent onset psychosis

8. First episode schizophrenia

9. Early schizophrenia

10. Recent onset schizophrenia

11. Physical health

12. Cardiometabolic

13. Cardiovascular

14. Obesity

15. Diabetes

16. Weight gain

Sample Search (PsycINFO):

ab,ti,kw("key worker" OR "case manage*" OR "care coordinat" ${ }^{* \prime}$ AND ab,ti,kw("early psychosis" OR "early schizophrenia" OR "first episode psychosis" OR "first

EIP_12937_Figure_1_.tif

This article is protected by copyright. All rights reserved. 


\section{University Library}

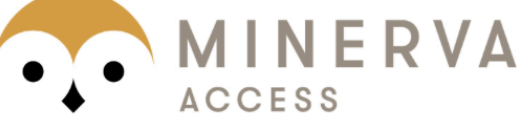

A gateway to Melbourne's research publications

Minerva Access is the Institutional Repository of The University of Melbourne

Author/s:

Lim, J;McCombe, G;Harrold, A;Brown, K;Clarke, M;Hanlon, D;Hennessy, L;O'Brien, S;Lyne, J;Corcoran, C;McGorry, P;Cullen, W

Title:

The role of key workers in improving physical health in first episode psychosis: A scoping review

Date:

2020-03-05

Citation:

Lim, J., McCombe, G., Harrold, A., Brown, K., Clarke, M., Hanlon, D., Hennessy, L., O'Brien, S., Lyne, J., Corcoran, C., McGorry, P. \& Cullen, W. (2020). The role of key workers in improving physical health in first episode psychosis: A scoping review. EARLY INTERVENTION IN PSYCHIATRY, 15 (1), pp.16-33. https://doi.org/10.1111/eip.12937.

Persistent Link:

http://hdl.handle.net/11343/275514 